\title{
Trophic transfer of microplastics and mixed contaminants in the marine food web and implications for human health
}

\author{
Maddison Carbery ${ }^{a}$, Wayne O'Connor ${ }^{\text {, }}$ Palanisami Thavamani ${ }^{a}{ }^{*}$ \\ a Global Centre for Environmental Remediation, The University of Newcastle, Australia \\ b Port Stephens Fisheries Institute, NSW Department of Primary Industries, Port \\ Stephens, Australia
}

* Corresponding author at: Global Centre for Environmental Remediation, The University of Newcastle, 2258, NSW, Australia.E-mail address: thava.palanisami@newcastle.edu.au (T. Palanisami).

This is the Accepted Manuscript of a paper published in Environment International. The final version may be accessed at https://doi.org/10.1016/j.envint.2018.03.007.

\section{Abstract}

Plastic litter has become one of the most serious threats to the marine environment. Over 690 marine species have been impacted by plastic debris with small plastic particles being observed in the digestive tract of organisms from different trophic levels. The physical and chemical properties of microplastics facilitate the sorption of contaminants to the particle surface, serving as a vector of contaminants to organisms following ingestion. Bioaccumulation factors for higher trophic organisms and impacts on wider marine food webs remain unknown. The main objectives of this review were to discuss the factors influencing microplastic ingestion; describe the biological impacts of associated chemical contaminants; highlight evidence for the trophic transfer of microplastics and contaminants within marine food webs and outline the future research priorities to address potential human health concerns. Controlled laboratory studies looking at the effects of microplastics and contaminants on model organisms employ nominal concentrations and consequently have little relevance to the real environment. Few studies have attempted to track the fate of microplastics and mixed contaminants through a complex marine food web using environmentally relevant concentrations to identify the real level of risk. To our knowledge, there has been no attempt to understand the transfer of microplastics and associated contaminants from seafood to humans and the implications for human health. Research is needed to determine bioaccumulation factors for popular seafood items in order to identify the potential impacts on human health.

\section{Introduction}

Microplastic (MP) research has received increasing attention over the past decade, following an increase in production and subsequent introduction of plastic to the marine environment. An estimated 8 million tonnes of plastic waste enters the ocean each year (Jambeck et al., 2015) and encounters with > 690 marine species have already been reported (Gall and Thompson, 
2015; Lavers and Bond, 2017). With no agreed upper size limit, microplastics are most often defined as plastics specifically manufactured or environmentally fragmented into particles $<5$ $\mathrm{mm}$ in size (Arthur et al., 2009). Microplastics occur in several forms; 1 ) primary MPs, plastic particles specifically manufactured for their abrasive qualities (e.g.; microbeads and industrial scrubbers), 2) secondary MPs originating from parent materials such as discarded plastic items and synthetic textiles and 3) tertiary MPs which includes any preproduction pellets used to mould plastic goods. Rivers, stormwater and sewage effluents are a major pathway of plastic debris to the ocean (Browne et al., 2011; Napper and Thompson, 2016; Lebreton et al., 2017). The progression from macro- to microplastics at sea is a result of physical and UV action, increasing the availability of smaller particles to a wider range of organisms, including those at the base of marine food webs (Browne et al., 2008; Wright et al., 2013). While the obvious physical impacts of ingestion include laceration, inflammation and in some cases starvation, the chemical effects of MP ingestion on an organisms daily functioning are less established. Plastics have been shown to accumulate various organic and inorganic contaminants from the surrounding water column (Rochman et al., 2013a; Rochman et al., 2014) The high surface area to volume ratio of small particles combined with non-polar surface facilitates the sorption of chemicals to the plastic surface, forming a complex mixture of contaminants available to marine organisms (Rochman et al., 2013b). The toxicity of MPs is largely size dependant generally the smaller the particle the further into the organism it can penetrate (Browne et al., 2008), releasing toxic chemicals under acidic gut conditions (Bakir et al., 2014; Batel et al., 2016). While numerous studies have investigated the effects of model chemicals on individual organisms and artificial food chains, to our knowledge no study has tracked the fate of microplastics and environmentally relevant chemical mixtures through a complex marine food web. Furthermore, there has been no attempt to understand the transfer of microplastics and associated contaminants from seafood to humans and the implications for human health.

This review aims to summarise what is known about the impacts of microplastics and chemical contaminants on marine organisms and highlight the implications for the trophic transfer of contaminants through the marine food web. Specifically, we (1) describe the fate of microplastics in the marine environment; (2) discuss factors influencing microplastic ingestion; (3) describe the biological impacts of chemical contaminants in the marine environment; (4) highlight evidence for the trophic transfer of microplastics and chemical contaminants to predators from prey species and (5) discuss the implications of a high seafood diet and outline the research priorities for addressing human health concerns.

\section{Fate of microplastics in the marine environment}

\subsection{Spatial distribution}

There have been many attempts to quantify MP concentrations in the different marine compartments, with beaches and coastlines often the focus of studies due to their ease of accessibility (Anderson et al., 2016). Offshore habitats have received far less attention, owing to the difficulties and costs associated with operating in deeper waters. For the few 
comprehensive surveys that do exist, a lack of standardised sampling methodology using different measures (e.g.; number of particles or weight of particles) and different units (e.g., L, $\mathrm{m} 3, \mathrm{~km} 2$ ), has resulted in disjointed spatial information from around the world (Hanvey et al., 2017) (Table 1). Evidence suggests that microplastics mainly exist as fibres and fragments in the marine environment, indicating waste waters and textiles as the primary pathway and source (Thompson et al., 2004; Browne et al., 2011; Claessens et al., 2011). Organisms within coastal food webs are more likely to ingest microplastics than those from offshore habitats, due to greater inputs from the land (Browne et al., 2010). Similarly, those inhabiting oceanic gyres and deep sea sediments are more likely to encounter microplastic particles than organisms in pelagic environments, due to greater concentrations within these compartments (Van Cauwenberghe et al., 2013; Cózar et al., 2014; Eriksen et al., 2014; Woodall et al., 2014).

Table 1. Microplastic concentrations reported for surface waters and subtidal sediments from around the world.

\begin{tabular}{|c|c|c|c|c|}
\hline Region & Country & Marine compartment & No. particles & Reference \\
\hline Australia & Australia & Surface water & $\begin{array}{l}4256.4 \pm 757.79 \mathrm{MPs} \mathrm{km}^{-2} \\
<0.18 \mathrm{MPs} \mathrm{\textrm {m } ^ { - 3 }}\end{array}$ & $\begin{array}{l}\text { Reisser et al. (2013) } \\
\text { Hall et al. (2015) }\end{array}$ \\
\hline \multirow[t]{3}{*}{ North America } & Canada & Surface water & $8-9200 \mathrm{MPs} \mathrm{m}^{-3}$ & Desforges et al. (2014) \\
\hline & USA & Surface water & $0-4696 \mathrm{MPs} \mathrm{m}^{-3}$ & Goldstein et al. (2013) \\
\hline & Alaska & Surface water & $0.004-0.19 \mathrm{MPs} \mathrm{m}^{-3}$ & Doyle et al. (2011) \\
\hline \multirow[t]{3}{*}{ Asia } & Japan & Sediment & $60-2020$ MPs $\mathrm{m}^{-2}$ & Fischer et al. (2015) \\
\hline & China & Surface water & $0.167 \pm 2461.5 \mathrm{MPs} \mathrm{m}^{-3}$ & Zhao et al. (2014) \\
\hline & & Sediment & $20-340 \mathrm{MPs} \mathrm{kg}^{-1}$ d.w. & Peng et al. (2017) \\
\hline \multirow[t]{3}{*}{ Africa } & Africa & Surface water & $257.9-1215$ MPs m $^{-3}$ & Nel et al. (2017) \\
\hline & & Sediment & $688.9-3308$ MPs m $^{-2}$ & Nel et al. (2017) \\
\hline & & & 400-1900 MPs kg ${ }^{-1}$ d.w. & Matsuguma et al. (2017) \\
\hline \multirow[t]{7}{*}{ Europe } & & Surface water & $0-1.5 \mathrm{MPs} \mathrm{m}^{-3}$ & Maes et al. (2017) \\
\hline & & & $0.25 \mathrm{MP} / \mathrm{m}^{-3}$ & Cózar et al. (2015) \\
\hline & & Sediment & 0-3146 MPs kg ${ }^{-1}$ d.w. & Maes et al. (2017) \\
\hline & & & 91.9-105.2 MPs kg ${ }^{-1}$ & Claessens et al. (2011) \\
\hline & & & $15 \pm 10 \mathrm{MPs} \mathrm{kg}{ }^{-1}$ d.w. & Graca et al. (2017) \\
\hline & & & $10 \pm 1 \mathrm{MPs} \mathrm{kg}^{-1}$ & Frias et al. (2017) \\
\hline & UK & Sediment & $>100 \mathrm{MPs} \mathrm{m}^{-2}$ & Ashton et al. (2010) \\
\hline \multirow[t]{2}{*}{ Arctic } & Arctic & Surface water & $0-131$ MPs $\mathrm{m}^{-3}$ & Lusher (2015) \\
\hline & & Sea ice & $38-234 \mathrm{MPs} \mathrm{m}^{-3}$ & Obbard et al. (2014) \\
\hline \multirow[t]{3}{*}{ Ocean Gyres } & North Pacific & Surface water & $116,000 \mathrm{MPs} \mathrm{km}^{-2}$ & Collignon et al. (2012) \\
\hline & South Pacific & & $26,898 \mathrm{MPs} \mathrm{km}^{-2}$ & Eriksen et al. (2013) \\
\hline & North Atlantic & & $20,328 \mathrm{MPs} \mathrm{km}^{-2}$ & Law et al. (2010) \\
\hline
\end{tabular}

\subsection{Assimilation by marine organisms}

Microplastics are being reported in an increasing number of marine organisms from different trophic levels, including zooplankton (Frias et al., 2014; Desforges et al., 2015), barnacles (Goldstein et al., 2013), bivalves (Van Cauwenberghe and Janssen, 2014), decapod crustaceans (Devriese et al., 2015), fish (Boerger et al., 2010; Lusher et al., 2013; Neves et al., 2015; Bellas et al., 2016), marine mammals (Besseling et al., 2015; Lusher et al., 2015) and seabirds (AveryGomm et al., 2012) (Table 2, Fig. 1). Microplastics occupy the same size range as plankton and grains of sand, making them accessible to a variety of organisms using different feeding strategies. Organisms may therefore ingest unknown quantities in conjunction with natural prey items, particularly non-selective feeders, which filter large quantities of water and sediment for organic nutrients (Browne et al., 2008; Cole et al., 2013; Farrell and Nelson, 2013). Nanoplastics ( $<100 \mathrm{~nm}$ ), either released to the environment or formed via the degradation of microplastics, may enter the food web via algae and bacteria, or be assimilated by filter feeding organisms (Koelmans et al., 2015; Mattsson et al., 2015). They are of particular concern as their 
small size enables them to permeate biological membranes, impacting on the functioning of blood cells and photosynthesis (Galloway, 2015). Nanoplastics are inherently more difficult to detect due to the limitations of sampling and analytical equipment (da Costa et al., 2016). Several methods that apply to nanomaterials are applied to nanoplastics in the laboratory, such as UV-VIS spectrometry, electron microscopy, field flow fractionation (FFF) or dynamic light scattering (DLS) (von der Kammer et al., 2012). Multiple wavelength UV-VIS has been used as a proxy to detect pinkdyed nanoparticles in Mytilus edulis and DLS to track the size of aggregates over time (Wegner et al., 2012). Presently, there are no studies reporting established analytical methods to detect nanoplastics in marine or freshwater bodies and so the real amount of nanoplastics in the environment is unknown (Mattsson et al., 2015).

Table 2. Microplastic concentration, polymer type, size and shape ingested by marine organisms in the natural environment.

\begin{tabular}{|c|c|c|c|c|c|c|}
\hline Country & Organism & MP load & MP type & MP Size & MP shape & Reference \\
\hline \multirow[t]{2}{*}{ Canada } & $\begin{array}{l}\text { Neocalanus } \\
\text { cristatus }\end{array}$ & $0.026 \mathrm{MPs} /$ org & - & $556 \pm 149 \mu \mathrm{m}$ & Fibres, fragments & Desforges et al. (2015) \\
\hline & Euphausia pacifica & $0.058 \mathrm{MPs}$ /org & - & $816 \pm 108 \mu \mathrm{m}$ & & \\
\hline \multirow[t]{7}{*}{ Europe } & Crangon crangon & $0.64 \pm 0.53 \mathrm{MPs} / \mathrm{g}$ w.w. & - & $>20 \mu \mathrm{m}$ & & Devriese et al. (2015) \\
\hline & 26 fish species & $0.27 \pm 0.63 \mathrm{MPs} /$ fish & $\begin{array}{l}\text { PP, PE, alkyd resin, rayon, } \\
\text { PE, nylon, acrylic }\end{array}$ & $0.217-4.81 \mathrm{~mm}$ & $\begin{array}{l}\text { Fibres }(65.8 \%), \\
\text { fragments }(34.2 \%)\end{array}$ & Neves et al. (2015) \\
\hline & $\begin{array}{l}\text { Clupea harengus } \\
\text { Scomber scombus }\end{array}$ & $0.19 \pm 0.61 \mathrm{MPs} /$ fish & PE, PA, PP, PS & $180 \mu \mathrm{m}-5 \mathrm{~mm}$ & Fragments (> 50\%) & Rummel et al. (2016) \\
\hline & Arenicola marina & $1.2 \pm 2.8 \mathrm{MPs} / \mathrm{g}$ w.w. & - & $>5 \mu \mathrm{m}$ & - & Van Cauwenberghe et al. (2015) \\
\hline & Mytilus edulis & $0.2 \pm 0.3 \mathrm{MP} / \mathrm{g}$ w.w. & - & $>5 \mu \mathrm{m}$ & - & \\
\hline & Mytilus edulis & $0.36 \pm 0.07 \mathrm{MPs} / \mathrm{g}$ w.w. & - & $>5 \mu \mathrm{m}$ & - & $\begin{array}{l}\text { Van Cauwenberghe and Janssen } \\
\text { (2014) }\end{array}$ \\
\hline & Crassostrea gigas & $0.47 \pm 0.16 \mathrm{MPs} / \mathrm{g}$ w.w. & - & $0.8 \mu \mathrm{m}$ & - & \\
\hline \multirow[t]{2}{*}{ UK } & 10 species fish & 1-15 MPs/fish & $\begin{array}{l}\text { Rayon, PA, PE, PS, LDPE, } \\
\text { acrylic }\end{array}$ & $0.13-5 \mathrm{~mm}$ & $\begin{array}{l}\text { Fibres }(68 \%) \text {, fragments } \\
(16 \%) \text {, beads }(12 \%)\end{array}$ & Lusher et al. (2013) \\
\hline & $\begin{array}{l}\text { Nephrops } \\
\text { norvegicus }\end{array}$ & $83 \%$ organisms & - & $<5 \mathrm{~mm}$ & - & Murray and Cowie (2011) \\
\hline \multirow[t]{2}{*}{ N. Pacific } & Lepas spp. & $33.5 \%$ barnacles & - & $>0.5 \mathrm{~mm}$ & - & Goldstein and Goodwin (2013) \\
\hline & 6 species fish & 1-83 MPs/fish & - & $1.0-2.79 \mathrm{~mm}$ & $\begin{array}{l}\text { Fragments }(94 \%) \text {, film }(2 \%) \text {, } \\
\text { fibres }(<1 \%)\end{array}$ & Boerger et al. (2010) \\
\hline
\end{tabular}

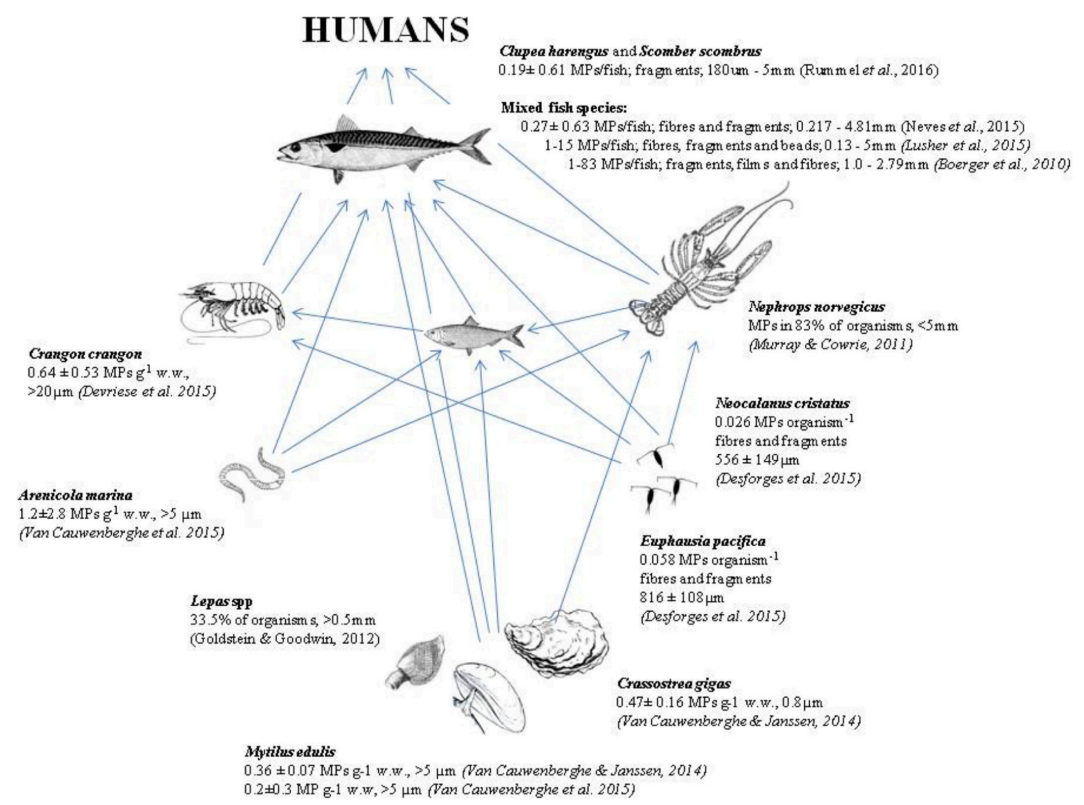

Fig. 1. A model marine food web indicating the load, size and shape of microplastics present in organisms across different trophic levels collected from the natural environment. 


\section{Factors influencing microplastic ingestion}

\subsection{Physical properties}

Microplastic size may be the most important factor in determining the range of organisms that ingest them (Andrady, 2011). Biological uptake is primarily dependent on the size of the particle in relation to natural prey items, while particle density determines the position in the water column and therefore the likelihood of encounter by an organism (Desforges et al., 2015). Organisms that inhabit surface waters are likely to encounter plastics with a specific density less than that of seawater such as polystyrene (PS), polypropylene (PP) and polyethylene (PE), while benthic organisms are susceptible to more dense or fouled plastics, including polyethylene terepthalate (PET) and polyvinyl chloride (PVC) (Cole et al., 2013). Over time, particles may be resuspended through bioturbation, storms or upwelling events and undergo changes to their physical characteristics such as size, shape and density. The processes of ageing and weathering contributes to the degradation of MPs and is driven by biotic (e.g.; microbial colonisation) and abiotic (e.g.; photo-oxidation) factors acting on the particle surface, resulting in modified surface topography and changes to the surface chemistry. As the surface area increases, so to do the number of sites available for microbial colonisation altering the particle density, buoyancy and sinking rate (Rummel et al., 2017).

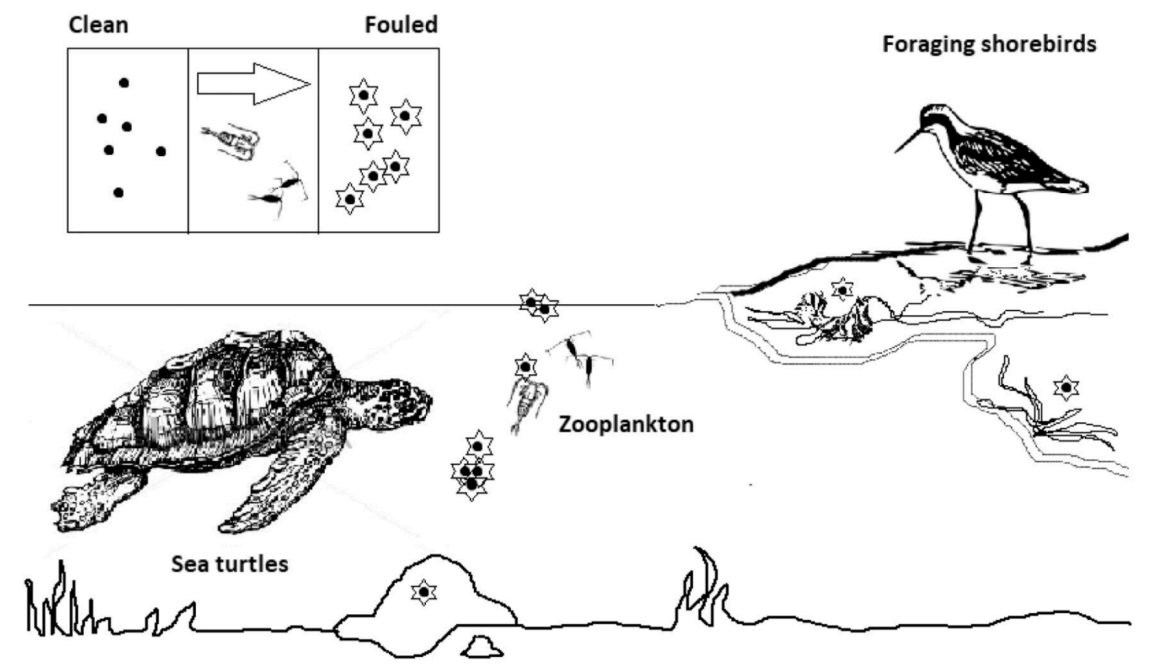

Fig. 2. Active selection of fouled plastic particles by marine organisms belonging to different trophic levels.

\subsection{Presence of biofilms}

Biofouling may play a major role in the mistaken identity of plastic as a nutritious food source (Kooi et al., 2017). Research suggests that the formation of biofilms may not only increase the likelihood of MP ingestion by altering the vertical distribution of the particle, but actually attract organisms relying on chemoreceptors to select prey through olfactory and gustatory cues (Fig. 2). A recent study of foraging shorebirds suggests that the breakdown of biofilms on the plastic surface produces a distinct dimethyl sulphide odour commonly associated with 
organic matter (Savoca et al., 2016). Nelms et al. (2016) suggest sea turtles ingest plastics for the same reason, with visual cues also playing an important role. The active selection of fouled plastic particles is not restricted to higher trophic organisms however. Copepods exposed to both clean and fouled PS particles ingested a higher frequency of aged particles exhibiting a biofilm (Vroom et al., 2016). With plastics able to trigger sensory responses in marine life from diverse trophic levels, it is vital to gain a holistic understanding of the real risks associated with plastic ingestion.

\subsection{Evidence from laboratory studies}

Laboratory studies provide a stronger weight of evidence for the effects of microplastic ingestion observed in organisms collected from the natural environment. Controlled studies enable researchers to tease apart the effects of different variables such as microplastic size (Browne et al., 2008; Cole et al., 2013; Van Cauwenberghe et al., 2015), shape (Graham and Thompson, 2009; Von Moos et al., 2012; Van Cauwenberghe et al., 2015), polymer type (Graham and Thompson, 2009; Avio et al., 2015a), concentration (Besseling et al., 2013; Setälä et al., 2014) and contaminant load (Besseling et al., 2013; Browne et al., 2013b; Oliveira et al., 2013; Chua et al., 2014; Avio et al., 2015a) on a variety of organisms (Table 3). Laboratory studies have successfully demonstrated the uptake of microplastic particles by zooplankton (Cole et al., 2013; Setälä et al., 2014; Cole et al., 2015), invertebrates (Browne et al., 2013b; Wright et al., 2013; Chua et al., 2014; Hämer et al., 2014), echinoderms (Graham and Thompson, 2009; Kaposi et al., 2014), mussels (Browne et al., 2008; Von Moos et al., 2012; Cole et al., 2015), oysters (Cole and Galloway, 2015; Sussarellu et al., 2016), crabs (Farrell and Nelson, 2013; Watts et al., 2014), fish (Batel et al., 2016) and recently coral (Hall et al., 2015) under controlled and simulated conditions. In order to understand the full extent of the consequences of MP ingestion on marine food webs, studies would benefit from a shift away from virgin-spiked plastics to aged plastics exposed at environmentally relevant concentrations and contaminant loads.

\section{Impact of chemicals in the marine environment}

\subsection{Plastic-chemical interactions}

The planetary-scale ubiquity and ever-increasing production of new and improved plastics makes plastic-contaminant interactions of great interest to toxicologists and ecologists. Despite plastics themselves being biochemically inert, a variety of additives including fillers, plasticizers, flame retardants, UV and thermal stabilizers, pigments and antimicrobial agents are introduced during the manufacture process to achieve the desired performance and appearance criteria (da Costa et al., 2017; Law, 2017). Plastic can therefore be a highly durable material, capable of withstanding harsh environmental conditions while remaining largely unchanged over time. The high surface area-tovolume ratio of microplastics facilitates the concentration of contaminants on the plastic surface up to six orders of magnitude compared to that of the ambient seawater (Mato et al., 2001). Hydrophobic contaminants sorb to non-polar surfaces including sediments and organic matter, but have a greater affinity for the hydrophobic surfaces associated with 
anthropogenic plastic debris (Hartmann et al., 2017). For example, polypropylene resin pellets sampled along the Japanese coastline exhibited polychlorinated bisphenols (PCBs), dichlorodiphenyldichloroethylene (DDE) and nonylphenol (NP) concentrations similar to suspended particles and bottom sediments collected from the same area, with aged pellets having higher concentrations of PCBs compared to younger pellets (Mato et al., 2001). From the Portuguese coast, PP and PE pellets contained polyaromatic hydrocarbons (PAHs), PCBs and dichlorodiphenyltrichloroethane (DDT) (Frias et al., 2010), while mixed plastic pellets collected from beaches in the UK were found to have sorbed a number of metals including cadmium and lead (Ashton et al., 2010). Field studies suggest that polymer type influences the sorption rate of PCBs and PAHs, with high density polyethylene (HDPE), low density polyethylene (LDPE) and PP accumulating greater concentrations of contaminants compared to PET and PVC (Rochman et al., 2013a). In contrast, sorption of metals to plastic was similar across polymer types, however equilibrium was not achieved over a 12 month period (Rochman et al., 2014). Time spent in the marine environment may therefore be an important factor in determining the risk of microplastic ingestion.

\subsection{Biological responses to chemical contaminants}

Much of the concern surrounding microplastics is due to the chemical additives and sorbed contaminants having the capacity to desorb into an organism (Bakir et al., 2014). Chemicals including phthalates, bisphenol A, flame retardants, PCBs, pesticides, fertilizers and heavy metals are known endocrine disruptors, carcinogens and mutagens (Tosetto et al., 2017). The leaching of additives from plastic combined with the sorption of chemicals to plastic renders microplastics a cocktail of toxic contaminants (Rochman, 2015). The biomagnification of organic pollutants from lower trophic levels to fish has been demonstrated (Kelly et al., 2007), as has the capacity of microplastics to act as a vector of these contaminants to amphipods (Chua et al., 2014), polychaetes (Besseling et al., 2013; Browne et al., 2013b), mussels (Avio et al., 2015a) and fish (Oliveira et al., 2013) (Table 3). Studies looking at the effects of MP ingestion on organisms have demonstrated a suite of reaction mechanisms including inflammation (Von Moos et al., 2012; Wright et al., 2013), increased immune activity (Browne et al., 2008), a reduction in feeding activity (Besseling et al., 2013; Cole et al., 2013; Wright et al., 2013; Watts et al., 2014; Cole et al., 2015), depletion of energy reserves (Wright et al., 2013; Watts et al., 2014), significant impacts on offspring (Sussarellu et al., 2016) and mortality of exposed individuals (Browne et al., 2013a; Oliveira et al., 2013). Trophic cascade and ecosystem-wide impacts remain unknown.

\section{Trophic transfer of microplastics and chemical contaminants in marine food webs}

\subsection{Trophic transfer of microplastic particles}

Evidence for the trophic transfer of microplastics comes from the quantification of MPs in field collected organisms, their natural predators and controlled feeding studies attempting to mimic the transfer of microplastics through artificial food chains (Farrell and Nelson, 2013; Setälä et 
al., 2014; Santana et al., 2017). The first suggestion came about when small plastic fragments were discovered in the scats of Hooker's sea lions (Phocartos hookeri) in conjunction with otoliths of the Myctophid fish species, Electrona subaspera (McMahon et al., 1999). Myctophids were previously shown to constitute a large proportion of the diet of two fur seals inhabiting the same geographical location, with $92 \%$ of all otoliths in the respective scats belonging to $\mathrm{E}$. subaspera (Goldsworthy et al., 1997). It was later confirmed that plastic particles were ingested by both the fish and fur seals along with natural prey items (Eriksson and Burton, 2003).

The first study to confirm the trophic transfer of plastics particles came about almost a decade after their discovery in sea lion scats. Polystyrene nanoparticles $(24 \mathrm{~nm})$ were fed through a freshwater food chain from algae (Scenedesmus sp.) to zooplankton (Daphnia magna) to goldfish (Carassius carassius), with noticeable effects on the feeding behaviour of $C$. carassius exposed to MPs (Cedervall et al., 2012). Exposed fish took twice the time to consume the same amount of zooplankton compared to control fish. Metabolic effects including weight loss, differences in the triglycerides:cholesterol ratio of blood serum and the distribution of cholesterol between muscle and liver were also reported (Cedervall et al., 2012). The transfer of microplastics and contaminants in a marine context could have significant consequences for seafood as a source of protein. Microplastic accumulation in lower trophic levels could potentially lead to cascading effects in marine food webs (Frias et al., 2014). Mysid shrimp, copepods, cladocerans, rotifers, polychaete larvae and ciliates were capable of ingesting $10 \mu \mathrm{m}$ fluorescent polystyrene microspheres, with copepods (Erytemora affine) and polychaete larvae (Marenzelleria spp.) demonstrating the transfer of ingested particles into Mysid shrimp (Neomysis integer, M. relicta and M. mixta) (Setälä et al., 2014). The authors concluded that MP ingestion by marine invertebrates was dependent upon feeding mode, suggesting some species may present more risk of contamination than others. Mussels have served as a model organism in feeding studies, due to their ability to filter large volumes of water and value as a commercial species. The blue mussel, Mytilus edulis was exposed to $0.5 \mu \mathrm{m}$ green fluorescent polystyrene microspheres before being fed to the common shore crab (Carcinus maenas) (Farrell and Nelson, 2013). The analysis of crab tissue later revealed the presence of MPs in the haemolymph, stomach, hepatopancreas, ovary and gills. In a first attempt to demonstrate MP transference through a multi-dimensional food web, the brown mussel (Perna perna) was incubated with 0.1-1 $\mu \mathrm{m}$ PVC microspheres and offered to two secondary consumers; fish (Spheoeroides greeleyi) and crabs (Callinectes ornatus) (Santana et al., 2017). Biotransference was confirmed to both fish and crabs, however the authors suggested negligible risk to higher trophic levels due to the rapid depuration of MPs.

\subsection{Trophic transfer of microplastics and sorbed contaminants}

Until recently, trophic transfer studies have focused on the effects of MPs in isolation, providing an inaccurate representation of real world scenarios. Just two studies have tracked the fate of contaminated MPs along a food chain in an effort to understand the potential for bioaccumulation and biomagnification within the marine food web. Batel et al. (2016) established a simple freshwater food chain consisting of Artemia sp. nauplii and zebrafish (Danio rerio) and demonstrated the trophic transfer of MPs (1-5 $\mu \mathrm{m}$ undisclosed composition 
and 10-20 $\mu \mathrm{m} \mathrm{PE}$ ) and the widespread polyaromatic hydrocarbon, benzo(a)pyrene (BaP). No noticeable effects were reported for virgin MPs, however BaP was shown to desorb in the gut epithelium and translocate to the liver. In an Australian study, Tosetto et al. (2017) explored the effects of aged PE microplastics (38-45 $\mu \mathrm{m})$ on a marine food chain using amphipods (Platorchestia smithi) and frill gobies (Bathygobius krefftii). Plastics were deployed in an urban bay for 2 months to facilitate the sorption of PAHs from seawater at an environmentally relevant concentration and fed to amphipods, which were offered to the gobies. Behavioural change in response to contaminants was monitored before and after exposure, with the authors concluding no significant effect on fish behaviour. These studies provide a basic understanding of the complex interactions among biological organisms and emerging contaminants. It is highly improbable that contaminants occur in isolation and the potential sorption and desorption kinetics between plastics, contaminants and biological tissue, particularly the effects on top predators, remains largely unknown. With a lack of robust data describing predator-prey contaminant transfer, knowledge is insufficient to inform an ecological risk assessment of marine microplastics and the implications of eating seafood.

\section{Implications for human health}

The uptake of plastic particles by humans can occur through the consumption of terrestrial and aquatic food products, drinking water and inhalation (Vethaak and Leslie, 2016). Despite seafood being a recognised source of contaminants to the human diet, the occurrence of microplastics in seafood is neither quantified nor regulated (Ziccardi et al., 2016). Seafood may be contaminated with microplastics through ingestion of natural prey, adherence to the organism's surface or during the processing and packaging phase (Cole et al., 2013; EFSA, 2016). Organisms that are eaten whole present a greater risk of exposure compared with those having had the digestive tract removed. For example, the popular European seafood items, Mytilus edulis, contained on average $0.36 \pm 0.07 \mathrm{MP}$ particles g-1 (w.w. soft tissue), while Crassostrea gigas contained $0.47 \pm 0.16 \mathrm{~g}-1$ (w.w. soft tissue) at the point of human consumption (Van Cauwenberghe and Janssen, 2014). Similarly, bivalves from a fish market in China contained between 2.1 and 10.5 MP particles g-1 (w.w. soft tissue) (Li et al., 2015). Whole fish purchased from fish markets in Indonesia and the USA revealed that $28 \%$ and $25 \%$ of all individuals had plastics $<4.5 \mathrm{~mm}$ present in their guts (Rochman et al., 2015), while commercially important species sourced from the Adriatic and Mediterranean Seas, English Channel and Portuguese coast demonstrated microplastic ingestion in the wild (Avio et al., 2015b; Neves et al., 2015; Bellas et al., 2016; Tanaka and Takada, 2016). Microplastics have also been reported in natural populations of the commercially important crustacean species, Crangon crangon (Devriese et al., 2015) and Nephrops norvegicus (Murray and Cowie, 2011). With plastics already present in a diversity of seafood items, there is strong support for the transfer of microplastic particles to humans (Fig. 3). Medical studies on both rats and humans have demonstrated the translocation of PS and PVC particles < $150 \mu \mathrm{m}$ from the gut cavity to the lymph and circulatory system (Volkheimer, 1975; Hussain et al., 2001). Very fine particles are capable of crossing cell membranes, the blood-brain barrier and the placenta, with documented effects including oxidative stress, cell damage, inflammation and impairment of energy allocation similar to that reported for marine organisms (refer to Table 3) (Vethaak and Leslie, 2016). Exposure to hydrophobic contaminants can be a direct result of the ingestion of contaminated microplastic 
particles, while secondary exposure can occur by ingesting fish, birds or other organisms that have accumulated contaminants within their tissue from previously egested microplastics (Ziccardi et al., 2016). Without further investigation and readily available data on MP loads in popular seafood items, it is difficult to perform a risk assessment of seafood for human consumption. Evidence suggests that human exposure to microplastics via seafood is plausible, however the contribution compared with other food and beverage products is unknown (Wright and Kelly, 2017). Research into the factors influencing MP ingestion by marine organisms, bioaccumulation factors for popular seafood species and their trophic interactions are urgently needed to identify which species should be eaten in moderation or avoided compared with those that are considered safe to eat. The quantity of micro- and nanoplastics in the environment is set to increase, and therefore this area of research requires urgent and thorough attention to discern the real impacts on human health.

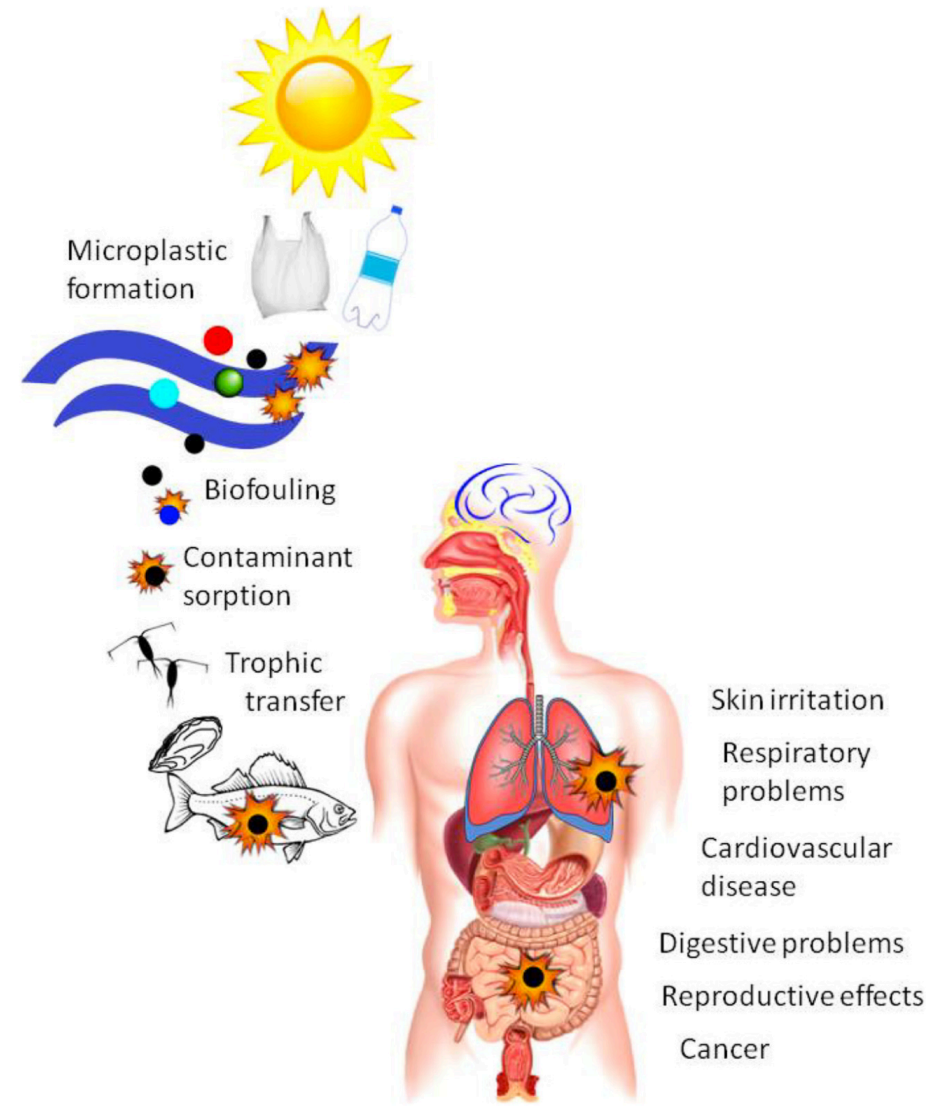

Fig. 3. Potential health effects resulting from the bioaccumulation and biomagnification of microplastics and chemical contaminants in the human body.

\section{Conclusion and recommended further research}

It is critical to manage the sources, understand the consequences and explore the fate of microplastics and emerging contaminants in the world's oceans. Evidence for the trophic transfer of microplastics comes from the quantification of MPs in field collected organisms, plastic particles identified in their natural predators and controlled feeding studies attempting 
to mimic the transfer of microplastics through artificial food chains. Laboratory exposure studies have become a popular means to explore bioaccumulation and biomagnification, however the implications for higher order predators and eventually humans are still poorly understood. Whether microplastics and associated contaminants are transferred to humans via their diet is unknown. With a lack of robust data describing predator-prey for MPs and associated contaminant transfer, knowledge is insufficient to inform a risk assessment of microplastics in the environment and the implications that may exist for eating seafood. Recommended actions to address the issue of microplastics include;

- Standardisation of sampling protocols, particle characterisation and analytical methods

- Comprehensive assessment of microplastic distribution and abundance in the various marine compartments, particularly for the southern hemisphere

- Comprehensive assessment of microplastics in organisms collected from the marine environment

- Use of environmentally relevant microplastic-chemical concentrations in feeding studies to determine the real level of risk

- Exposure studies using complex mixtures of contaminants relevant to polluted environments

- Trophic transfer studies to determine the capacity for microplastics to transport contaminants through marine food webs, facilitating

- the bioaccumulation and biomagnification of microplastics and associated contaminants in higher order predators.

- Ecological risk assessment of marine microplastics and trophic cascade effects

- Comprehensive assessment of microplastic and contaminant concentrations in seafood species and the impact cooking may have on the desportion and subsequent bioaccessibility of contaminants to better understand the implications for human health

- In-vitro studies to determine the fate and behaviour of microplastics, their endogenous additives and sorbed contaminants in the human GIT

- New approaches and methods to detect and quantify nanoplastics in the environment, thereby generating a better understanding of the ecological and human health impacts, as well as the final fate of minute plastic particles

\section{Declaration of interest}

None.

\section{Acknowledgements}

This work was funded by The University of Newcastle, The City of Newcastle and Lake Macquarie City Council. The authors would like to thank the NSW DPI Fisheries Institute and Tangaroa Blue volunteers for their support. 
Table 3. Controlled feeding studies showing adverse biological impacts to marine organisms following exposure to virgin and spiked microplastics of varying polymer type, size and concentration (concn). $\mathrm{PS}=$ polystyrene, $\mathrm{PE}=$ polyethylene, $\mathrm{UPVC}=$ unplasticised polyvinylchloride, $\mathrm{PVC}=$ polyvinylchloride, $\mathrm{HDPE}=$ high density polyethylene, $\mathrm{PP}=$ polypropylene and $\mathrm{SW}=$ sea water.

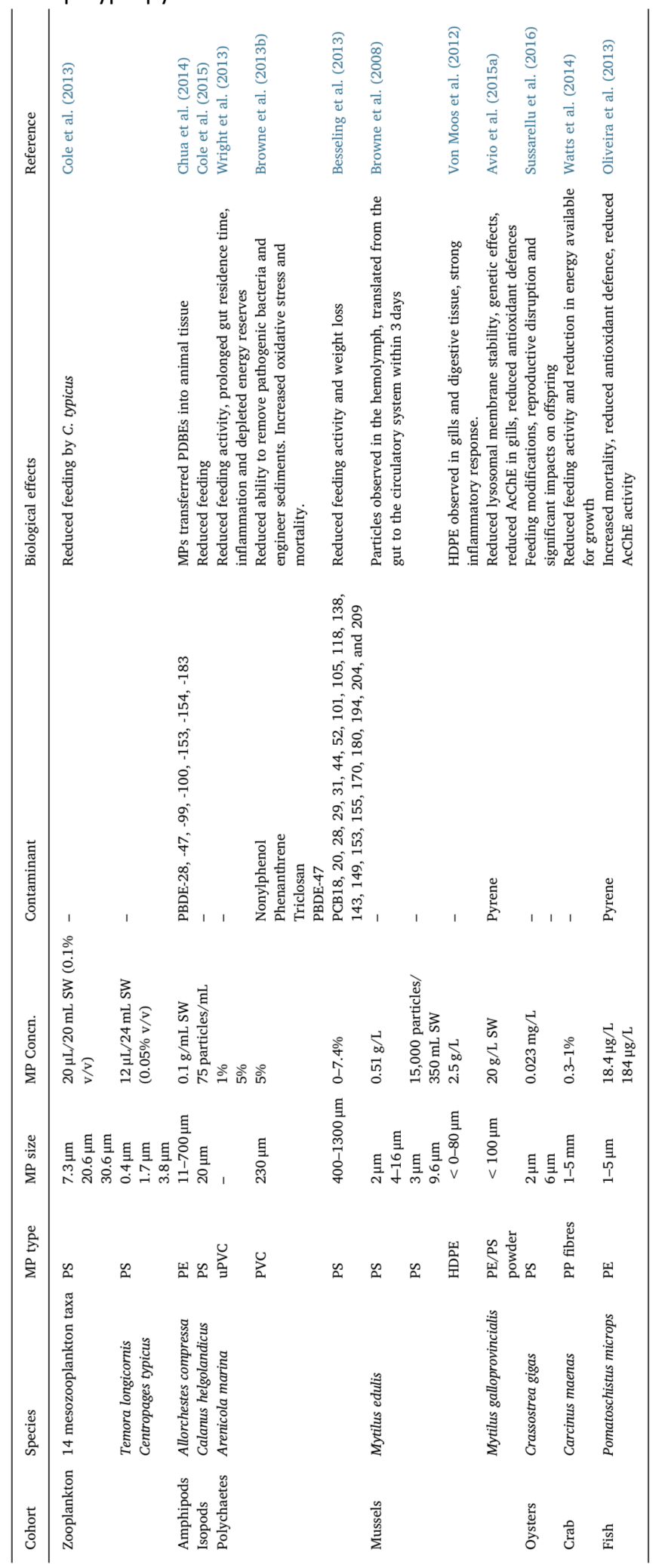




\section{References}

Anderson, J.C., Park, B.J., Palace, V.P., 2016. Microplastics in aquatic environments: implications for Canadian ecosystems. Environ. Pollut. 218, 269-280.

http://dx.doi.org/10.1016/j.envpol.2016.06.074.

Andrady, A.L., 2011. Microplastics in the marine environment. Mar. Pollut. Bull. 62 (8), 15961605. http://dx.doi.org/10.1016/j.marpolbul.2011.05.030.

Arthur, C., Baker, J., Bamford, H., Barnea, N., Lohmann, R., McElwee, K., et al., 2009. Summary of the International Research Workshop on the Occurrence, Effects, and Fate of Microplastic Marine Debris. (Retrieved from).

Ashton, K., Holmes, L., Turner, A., 2010. Association of metals with plastic production pellets in the marine environment. Mar. Pollut. Bull. 60 (11), 2050-2055.

http://dx.doi.org/10.1016/j.marpolbul.2010.07.014.

Avery-Gomm, S., O'Hara, P.D., Kleine, L., Bowes, V., Wilson, L.K., Barry, K.L., 2012. Northern fulmars as biological monitors of trends of plastic pollution in the eastern North Pacific. Mar. Pollut. Bull. 64. http://dx.doi.org/10.1016/j.marpolbul.2012.04.017.

Avio, C.G., Gorbi, S., Milan, M., Benedetti, M., Fattorini, D., d'Errico, G., ... Regoli, F., $2015 a$. Pollutants bioavailability and toxicological risk from microplastics to marine mussels. Environ. Pollut. 198, 211-222. http://dx.doi.org/10.1016/j.envpol.2014.12.021.

Avio, C.G., Gorbi, S., Regoli, F., 2015b. Experimental development of a new protocol for extraction and characterization of microplastics in fish tissues: first observations in commercial species from Adriatic Sea. Mar. Environ. Res.

http://dx.doi.org/10.1016/j.marenvres.2015.06.014.

Bakir, A., Rowland, S.J., Thompson, R.C., 2014. Enhanced desorption of persistent organic pollutants from microplastics under simulated physiological conditions. Environ. Pollut. 185. http://dx.doi.org/10.1016/j.envpol.2013.10.007.

Batel, A., Linti, F., Scherer, M., Erdinger, L., Braunbeck, T., 2016. Transfer of benzo[a] pyrene from microplastics to Artemia nauplii and further to zebrafish via a trophic food web experiment: CYP1A induction and visual tracking of persistent organic pollutants. Environ. Toxicol. Chem. 35 (7), 1656-1666. http://dx.doi.org/10.1002/etc.3361.

Bellas, J., Martínez-Armental, J., Martínez-Cámara, A., Besada, V., Martínez-Gómez, C., 2016. Ingestion of microplastics by demersal fish from the Spanish Atlantic and Mediterranean coasts. Mar. Pollut. Bull. 109 (1), 55-60. http://dx.doi.org/10.1016/j.marpolbul.2016.06.026.

Besseling, E., Wegner, A., Foekema, E.M., van den Heuvel-Greve, M.J., Koelmans, A.A., 
2013. Effects of microplastic on fitness and PCB bioaccumulation by the lugworm Arenicola marina (L.). Environ. Sci. Technol. 47. http://dx.doi.org/10.1021/es302763x.

Besseling, E., Foekema, E.M., Van Franeker, J.A., Leopold, M.F., Kühn, S., Bravo Rebolledo, E.L., ... Koelmans, A.A., 2015. Microplastic in a macro filter feeder: humpback whale Megaptera novaeangliae. Mar. Pollut. Bull. 95 (1), 248-252.

http://dx.doi.org/10.1016/j.marpolbul.2015.04.007.

Boerger, C.M., Lattin, G.L., Moore, S.L., Moore, C.J., 2010. Plastic ingestion by planktivorous fishes in the North Pacific Central Gyre. Mar. Pollut. Bull. 60 (12), 2275-2278.

Retrieved from.

http://ac.els-cdn.com/S0025326X10003814/1-s2.0S0025326X10003814-

main.pdf? tid=947cf33a-3133-11e7-b2bd-

00000aabOf6b\&acdnat=1493948506 83bb7c4daed01ed2374dd1e3264b3a32.

Browne, M.A., Dissanayake, A., Galloway, T.S., Lowe, D.M., Thompson, R.C., 2008. Ingested microscopic plastic translocates to the circulatory system of the mussel, Mytilus edulis (L). Environ. Sci. Technol. 42. http://dx.doi.org/10.1021/es800249a.

Browne, M.A., Galloway, T.S., Thompson, R.C., 2010. Spatial patterns of plastic debris along estuarine shorelines. Environ. Sci. Technol. 44. http://dx.doi.org/10.1021/es903784e.

Browne, M., Crump, P., Niven, S.J., Teuten, E., Tonkin, A., Galloway, T., Thompson, R., 2011. Accumulation of microplastic on shorelines worldwide: sources and sinks. Environ. Sci. Technol. 45. http://dx.doi.org/10.1021/es201811s.

Browne, Mark A., Niven, Stewart J., Galloway, Tamara S., Rowland, Steve J., Thompson, Richard C., 2013a. Microplastic moves pollutants and additives to worms, reducing functions linked to health and biodiversity. Curr. Biol. 23 (23), 2388-2392.

http://dx.doi.org/10.1016/j.cub.2013.10.012.

Browne, M.A., Niven, S.J., Galloway, T.S., Rowland, S.J., Thompson, R.C., 2013b. Microplastic moves pollutants and additives to worms, reducing functions linked to health and biodiversity. Curr. Biol. 23. http://dx.doi.org/10.1016/i.cub.2013.10.012.

Cedervall, T., Hansson, L.-A., Lard, M., Frohm, B., Linse, S., 2012. Food chain transport of nanoparticles affects behaviour and fat metabolism in fish. PLoS One 7 (2), e32254. http://dx.doi.org/10.1371/journal.pone.0032254.

Chua, E.M., Shimeta, J., Nugegoda, D., Morrison, P.D., Clarke, B.O., 2014. Assimilation of polybrominated diphenyl ethers from microplastics by the marine amphipod, Allorchestes compressa. Environ. Sci. Technol. 48. http://dx.doi.org/10.1021/ es405717z. 
Claessens, M., de Meester, S., van Landuyt, L., de Clerck, K., Janssen, C.R., 2011. Occurrence and distribution of microplastics in marine sediments along the Belgian coast. Mar. Pollut. Bull. 62. http://dx.doi.org/10.1016/j.marpolbul.2011.06.030.

Cole, M., Galloway, T.S., 2015. Ingestion of nanoplastics and microplastics by Pacific oyster larvae. Environ. Sci. Technol. 49 (24), 14625-14632. http://dx.doi.org/10.1021/acs.est.5b04099.

Cole, M., Lindeque, P., Fileman, E., Halsband, C., Goodhead, R., Moger, J., 2013. Microplastic ingestion by zooplankton. Environ. Sci. Technol. 47.

Cole, M., Lindeque, P., Fileman, E., Halsband, C., Galloway, T.S., 2015. The impact of polystyrene microplastics on feeding, function and fecundity in the marine copepod Calanus helgolandicus. Environ. Sci. Technol. 49. http://dx.doi.org/10.1021/es504525u.

Collignon, A., Hecq, J.H., Galagani, F., Voisin, P., Collard, F., Goffart, A., 2012. Neustonic microplastic and zooplankton in the north western Mediterranean Sea. Mar. Pollut. Bull. 64. http://dx.doi.org/10.1016/j.marpolbul.2012.01.011.

da Costa, J.P., Duarte, A.C., Rocha-Santos, T.A.P., 2017. Chapter 1 - microplastics - occurrence, fate and behaviour in the environment. In: Teresa, A.P.R.S., Armando, C.D. (Eds.), Comprehensive Analytical Chemistry. Volume 75. Elsevier, pp. 1-24.

Cózar, A., Echevarría, F., González-Gordillo, J.I., Irigoien, X., Ubeda, B., Hernández-León, S., 2014. Plastic debris in the open ocean. Proc. Natl. Acad. Sci. U. S. A. 111. http://dx.doi.org/10.1073/pnas.1314705111.

Cózar, A., Sanz-Martín, M., Martí, E., González-Gordillo, J.I., Ubeda, B., Gálvez, J.Á., ... Duarte, C.M., 2015. Plastic accumulation in the Mediterranean Sea. PLoS One 10 (4), e0121762 Retrieved from. https://www.ncbi.nlm.nih.gov/pmc/articles/PMC4382178/pdf/pone.0121762.pdf.

da Costa, J.P., Santos, P.S.M., Duarte, A.C., Rocha-Santos, T., 2016. (Nano)plastics in the environment - sources, fates and effects. Sci. Total Environ. 566-567, 15-26.

http://dx.doi.org/10.1016/j.scitotenv.2016.05.041.

Desforges, J.P., Galbraith, M., Dangerfield, N., Ross, P.S., 2014. Widespread distribution of microplastics in subsurface seawater in the NE Pacific Ocean. Mar. Pollut. Bull. 79. http://dx.doi.org/10.1016/j.marpolbul.2013.12.035.

Desforges, J.P., Galbraith, M., Ross, P.S., 2015. Ingestion of microplastics by zooplankton in the Northeast Pacific Ocean. Arch. Environ. Contam. Toxicol. 69. http://dx.doi.org/10.1007/s00244-015-0172-5. 
Devriese, L.I., van der Meulen, M.D., Maes, T., Bekaert, K., Paul-Pont, I., Frère, L., ... Vethaak, A.D., 2015. Microplastic contamination in brown shrimp (Crangon crangon, Linnaeus 1758) from coastal waters of the Southern North Sea and Channel area. Mar. Pollut. Bull. 98 (1-2), 179-187. http://dx.doi.org/10.1016/j.marpolbul.2015.06.051.

Doyle, M.J., Watson, W., Bowlin, N.M., Sheavly, S.B., 2011. Plastic particles in coastal pelagic ecosystems of the Northeast Pacific Ocean. Mar. Environ. Res. 71 (1), 41-52.

http://dx.doi.org/10.1016/j.marenvres.2010.10.001.

EFSA, 2016. Presence of microplastics and nanoplastics in food, with particular focus on seafood. Panel on contaminants in the food chain. EFSA J. 14 (6) (e04501-n/a).

https://doi.org/10.2903/j.efsa.2016.4501.

Eriksen, M., Maximenko, N., Thiel, M., Cummins, A., Lattin, G., Wilson, S., ... Rifman, S., 2013. Plastic pollution in the South Pacific subtropical gyre. Mar. Pollut. Bull. 68 (1-2), 71-76. http://dx.doi.org/10.1016/j.marpolbul.2012.12.021.

Eriksen, M., Lebreton, L.C.M., Carson, H.S., Thiel, M., Moore, C.J., Borerro, J.C., ... Reisser, J., 2014. Plastic pollution in the world's oceans: more than 5 trillion plastic pieces weighing over 250,000 tons afloat at sea. PLoS One 9 (12), e111913.

http://dx.doi.org/10.1371/journal.pone.0111913.

Eriksson, C., Burton, H., 2003. Origins and biological accumulation of small plastic particles in fur seals from Macquarie Island. Ambio 32. http://dx.doi.org/10.1579/00447447-32.6.380.

Farrell, P., Nelson, K., 2013. Trophic level transfer of microplastic: Mytilus edulis (L.) to Carcinus maenas (L.). Environ. Pollut. 177, 1-3. http://dx.doi.org/10.1016/i.envpol.2013.01.046.

Fischer, V., Elsner, N.O., Brenke, N., Schwabe, E., Brandt, A., 2015. Plastic pollution of the KurilKamchatka Trench area (NW pacific). Deep-Sea Res. II 111.

http://dx.doi.org/10.1016/j.dsr2.2014.08.012.

Frias, J.P.G.L., Sobral, P., Ferreira, A.M., 2010. Organic pollutants in microplastics from two beaches of the Portuguese coast. Mar. Pollut. Bull. 60 (11), 1988-1992.

http://dx.doi.org/10.1016/j.marpolbul.2010.07.030.

Frias, J.P.G.L., Otero, V., Sobral, P., 2014. Evidence of microplastics in samples of zooplankton from Portuguese coastal waters. Mar. Environ. Res. 95, 89-95.

http://dx.doi.org/10.1016/j.marenvres.2014.01.001.

Frias, J.P.G.L., Carriço, R., Rodriguez, Y., Rios, N., Garcia, S., Pham, C., 2017. Marine litter accumulation in the Azorean Archipelago: Azorlit preliminary data. In: Fate and Impact of Microplastics in Marine Ecosystems. Elsevier. http://dx.doi.org/10.1016/B978-0-12-8122716.00047-8. (pp. 48). 
Gall, S.C., Thompson, R.C., 2015. The impact of debris on marine life. Mar. Pollut. Bull. 92 (1), 170-179. http://dx.doi.org/10.1016/j.marpolbul.2014.12.041.

Galloway, T.S., 2015. Micro- and nano-plastics and human health. In: Bergmann, M., Gutow, L., Klages, M. (Eds.), Marine Anthropogenic Litter. Springer International Publishing, Cham, pp. 343-366. http://dx.doi.org/10.1007/978-3-319-16510-3 13.

Goldstein, M.C., Goodwin, D.S., 2013. Gooseneck barnacles (Lepas spp.) ingest microplastic debris in the North Pacific Subtropical Gyre. PeerJ. 1, e184.

Goldstein, M.C., Titmus, A.J., Ford, M., 2013. Scales of spatial heterogeneity of plastic marine debris in the northeast Pacific Ocean. PLoS One 8.

http://dx.doi.org/10.1371/journal.pone.0080020.

Goldsworthy, S., Hindell, M., Crowley, H., 1997. Diet and diving behaviour of sympatric fur seals Arctocephalus gazella and A. tropicalis at Macquarie Island, Marine Mammal Research in the Southern Hemisphere. Status Ecol. Med. 1, 151-163.

Graca, B., Szewc, K., Zakrzewska, D., Dołęga, A., Szczerbowska-Boruchowska, M., 2017. Sources and fate of microplastics in marine and beach sediments of the Southern Baltic Sea-a preliminary study. Environ. Sci. Pollut. Res. 24 (8), 7650-7661. http://dx.doi.org/10.1007/s11356-017-8419-5.

Graham, E.R., Thompson, J.T., 2009. Deposit- and suspension-feeding sea cucumbers (Echinodermata) ingest plastic fragments. J. Exp. Mar. Biol. Ecol. 368 (1), 22-29. http://dx.doi.org/10.1016/j.jembe.2008.09.007.

Hall, N.M., Berry, K.L.E., Rintoul, L., Hoogenboom, M.O., 2015. Microplastic ingestion by scleractinian corals. Mar. Biol. 162 (3), 725-732. http://dx.doi.org/10.1007/s00227015-2619-7.

Hämer, J., Gutow, L., Köhler, A., Saborowski, R., 2014. Fate of microplastics in the marine isopod Idotea emarginata. Environ. Sci. Technol. 48. http://dx.doi.org/10.1021/es501385y.

Hanvey, J.S., Lewis, P.J., Lavers, J.L., Crosbie, N.D., Pozo, K., Clarke, B.O., 2017. A review of analytical techniques for quantifying microplastics in sediments. Anal. Methods 9 (9), 13691383. http://dx.doi.org/10.1039/C6AY02707E.

Hartmann, N.B., Rist, S., Bodin, J., Jensen, L.H.S., Schmidt, S.N., Mayer, P., ... Baun, A., 2017. Microplastics as vectors for environmental contaminants: exploring sorption, desorption, and transfer to biota. Integr. Environ. Assess. Manag. 13 (3), 488-493.

http://dx.doi.org/10.1002/ieam.1904.

Hussain, N., Jaitley, V., Florence, A.T., 2001. Recent advances in the understanding of uptake of microparticulates across the gastrointestinal lymphatics. Adv. Drug Deliv. Rev. 50 (1), 107-142. http://dx.doi.org/10.1016/S0169-409X(01)00152-1. 
Jambeck, J.R., Geyer, R., Wilcox, C., Siegler, T.R., Perryman, M., Andrady, A., 2015. Plastic waste inputs from land into the ocean. Science 347. http://dx.doi.org/10.1126/science.1260352.

Kaposi, K.L., Mos, B., Kelaher, B.P., Dworjanyn, S.A., 2014. Ingestion of microplastic has limited impact on a marine larva. Environ. Sci. Technol. 48. http://dx.doi.org/10.1021/es404295e. Kelly, B.C., Ikonomou, M.G., Blair, J.D., Morin, A.E., Gobas, F.A.P.C., 2007. Food webspecific biomagnification of persistent organic pollutants. Science 317 (5835), 236-239. http://dx.doi.org/10.1126/science.1138275.

Koelmans, A.A., Besseling, E., Shim, W.J., 2015. Nanoplastics in the aquatic environment. Critical review. In: Bergmann, M., Gutow, L., Klages, M. (Eds.), Marine Anthropogenic Litter. Springer International Publishing, Cham, pp. 325-340. http://dx.doi.org/10.1007/978-3-31916510-3 12.

Kooi, M., Nes, E.H.v., Scheffer, M., Koelmans, A.A., 2017. Ups and downs in the ocean: effects of biofouling on vertical transport of microplastics. Environ. Sci. Technol. 51 (14), 7963-7971. http://dx.doi.org/10.1021/acs.est.6b04702.

Lavers, J.L., Bond, A.L., 2017. Exceptional and rapid accumulation of anthropogenic debris on one of the world's most remote and pristine islands. Proc. Natl. Acad. Sci. 114 (23), 6052-6055. http://dx.doi.org/10.1073/pnas.1619818114.

Law, K.L., 2017. Plastics in the marine environment. Annu. Rev. Mar. Sci. 9, 205-229. Law, K.L., Morét-Ferguson, S., Maximenko, N.A., Proskurowski, G., Peacock, E.E., Hafner, J., 2010. Plastic accumulation in the North Atlantic subtropical gyre. Science 329.

http://dx.doi.org/10.1126/science.1192321.

Lebreton, L.C.M., van der Zwet, J., Damsteeg, J.-W., Slat, B., Andrady, A., Reisser, J., 2017. River Plastic Emissions to the World's Oceans. 8, 15611. http://dx.doi.org/10.1038/ncomms15611. https://www.nature.com/articles/ncomms15611\#supplementary-information.

Li, J., Yang, D., Li, L., Jabeen, K., Shi, H., 2015. Microplastics in commercial bivalves from China. Environ. Pollut. 207, 190-195. http://dx.doi.org/10.1016/j.envpol.2015.09.018.

Lusher, A., 2015. Microplastics in the marine environment: distribution, interactions and effects. In: Bergmann, L.G.M.K.M. (Ed.), Marine Anthropogenic Litter. Springer, Berlin, pp. 245308.

Lusher, A.L., McHugh, M., Thompson, R.C., 2013. Occurrence of microplastics in the gastrointestinal tract of pelagic and demersal fish from the English Channel. Mar. Pollut. Bull. 67 (1-2), 94-99. http://dx.doi.org/10.1016/j.marpolbul.2012.11.028. 
Lusher, A.L., Hernandez-Milian, G., O'Brien, J., Berrow, S., O'Connor, I., Officer, R., 2015.

Microplastic and macroplastic ingestion by a deep diving, oceanic cetacean: the True's beaked whale Mesoplodon mirus. Environ. Pollut. 199. http://dx.doi.org/10.1016/j.envpol.2015.01.023.

Maes, T., Jessop, R., Wellner, N., Haupt, K., Mayes, A.G., 2017. A rapid-screening approach to detect and quantify microplastics based on fluorescent tagging with Nile Red. Sci. Rep. 7, 44,501. http://dx.doi.org/10.1038/srep44501.

http://dharmasastra.live.cf.private.springer.com/articles/srep44501\#supplementaryinformatio $\underline{\mathrm{n}}$.

Mato, Y., Isobe, T., Takada, H., Kanehiro, H., Ohtake, C., Kaminuma, T., 2001. Plastic resin pellets as a transport medium for toxic chemicals in the marine environment. Environ. Sci. Technol. 35. http://dx.doi.org/10.1021/es0010498.

Matsuguma, Y., Takada, H., Kumata, H., Kanke, H., Sakurai, S., Suzuki, T., ... Newman, B., 2017. Microplastics in sediment cores from Asia and Africa as indicators of temporal trends in plastic pollution. Arch. Environ. Contam. Toxicol. http://dx.doi.org/10.1007/s00244-017-0414-9.

Mattsson, K., Hansson, L.A., Cedervall, T., 2015. Nano-plastics in the aquatic environment. Environ. Sci. Process. Impact. 17 (10), 1712-1721. http://dx.doi.org/10.1039/C5EM00227C.

McMahon, C.R., Holley, D., Robinson, S., 1999. The diet of itinerant male Hooker's sea lions, Phocarctos hookeri, at sub-Antarctic Macquarie Island. Wildl. Res. 26 (6), 839-846. http://dx.doi.org/10.1071/WR98079.

Murray, F., Cowie, P.R., 2011. Plastic contamination in the decapod crustacean Nephrops norvegicus (Linnaeus, 1758). Mar. Pollut. Bull. 62 (6), 1207-1217.

http://dx.doi.org/10.1016/i.marpolbul.2011.03.032.

Napper, I.E., Thompson, R.C., 2016. Release of synthetic microplastic plastic fibres from domestic washing machines: effects of fabric type and washing conditions. Mar. Pollut. Bull. 112 (1), 39-45. http://dx.doi.org/10.1016/j.marpolbul.2016.09.025.

Nel, H.A., Hean, J.W., Noundou, X.S., Froneman, P.W., 2017. Do microplastic loads reflect the population demographics along the southern African coastline? Mar. Pollut. Bull. 115 (1), 115119. http://dx.doi.org/10.1016/j.marpolbul.2016.11.056.

Nelms, S.E., Duncan, E.M., Broderick, A.C., Galloway, T.S., Godfrey, M.H., Hamann, M., ... Godley, B.J., 2016. Plastic and marine turtles: a review and call for research. ICES J. Mar. Sci. 73 (2), 165-181. http://dx.doi.org/10.1093/icesjms/fsv165.

Neves, D., Sobral, P., Ferreira, J.L., Pereira, T., 2015. Ingestion of microplastics by commercial fish off the Portuguese coast. Mar. Pollut. Bull. 101 (1), 119-126.

http://dx.doi.org/10.1016/i.marpolbul.2015.11.008. 
Obbard, R.W., Sadri, S., Wong, Y.Q., Khitun, A.A., Baker, I., Thompson, R.C., 2014. Global warming releases microplastic legacy frozen in Arctic Sea ice. Earth. Futur. 2 (6), 315-320. http://dx.doi.org/10.1002/2014EF000240.

Oliveira, M., Ribeiro, A., Hylland, K., Guilhermino, L., 2013. Single and combined effects of microplastics and pyrene on juveniles ( $0+$ group) of the common goby Pomatoschistus microps (Teleostei, Gobiidae). Ecol. Indic. 34. http://dx.doi.org/10.1016/j.ecolind.2013.06.019.

Peng, G., Zhu, B., Yang, D., Su, L., Shi, H., Li, D., 2017. Microplastics in sediments of the Changjiang Estuary, China. Environ. Pollut. 225, 283-290.

http://dx.doi.org/10.1016/j.envpol.2016.12.064.

Reisser, J., Shaw, J., Wilcox, C., Hardesty, B.D., Proietti, M., Thums, M., Pattiaratchi, C., 2013. Marine plastic pollution in waters around Australia: characteristics, concentrations, and pathways. PLoS One 8 (11), e80466. http://dx.doi.org/10.1371/journal.pone.0080466.

Rochman, C.M., 2015. The complex mixture, fate and toxicity of chemicals associated with plastic debris in the marine environment. In: Bergmann, M., Gutow, L., Klages, M. (Eds.), Marine Anthropogenic Litter. Springer International Publishing, Cham, pp. 117-140.

http://dx.doi.org/10.1007/978-3-319-16,510-3_5.

Rochman, C., Hoh, E., Hentschel, B., Kaye, S., 2013a. Long-term field measurement of sorption of organic contaminants to five types of plastic pellets: implications for plastic marine debris. Environ. Sci. Technol. 47 (3), 1646-1654. http://dx.doi.org/10.1021/es303700s.

Rochman, C., Hoh, E., Kurobe, T., Teh, S.J., 2013b. Ingested plastic transfers hazardous chemicals to fish and induces hepatic stress. Sci. Rep. 3. http://dx.doi.org/10.1038/srep03263.

Rochman, C.M., Hentschel, B.T., Teh, S.J., 2014. Long-term sorption of metals is similar among plastic types: implications for plastic debris in aquatic environments. PLoS One 9 (1), e85433. http://dx.doi.org/10.1371/journal.pone.0085433.

Rochman, C.M., Tahir, A., Williams, S.L., Baxa, D.V., Lam, R., Miller, J.T., ... Teh, S.J., 2015. Anthropogenic debris in seafood: plastic debris and fibers from textiles in fish and bivalves sold for human consumption. Sci. Rep. 5, 14,340. http://dx.doi.org/10.1038/srep14340. https://www.nature.com/articles/srep14340\#supplementaryinformation.

Rummel, C.D., Löder, M.G.J., Fricke, N.F., Lang, T., Griebeler, E.-M., Janke, M., Gerdts, G., 2016. Plastic ingestion by pelagic and demersal fish from the North Sea and Baltic Sea. Mar. Pollut. Bull. 102 (1), 134-141. http://dx.doi.org/10.1016/j.marpolbul.2015.11.043.

Rummel, C.D., Jahnke, A., Gorokhova, E., Kühnel, D., Schmitt-Jansen, M., 2017. Impacts of biofilm formation on the fate and potential effects of microplastic in the aquatic environment. Environ. Sci. Technol. Lett. 4 (7), 258-267. http://dx.doi.org/10.1021/acs.estlett.7b00164. 
Santana, M.F.M., Moreira, F.T., Turra, A., 2017. Trophic transference of microplastics under a low exposure scenario: insights on the likelihood of particle cascading along marine food-webs. Mar. Pollut. Bull. http://dx.doi.org/10.1016/j.marpolbul.2017.05.061.

Savoca, M.S., Wohlfeil, M.E., Ebeler, S.E., Nevitt, G.A., 2016. Marine plastic debris emits a keystone infochemical for olfactory foraging seabirds. Sci. Adv. 2 (11).

http://dx.doi.org/10.1126/sciadv.1600395.

Setälä, O., Fleming-Lehtinen, V., Lehtiniemi, M., 2014. Ingestion and transfer of microplastics in the planktonic food web. Environ. Pollut. 185, 77-83.

http://dx.doi.org/10.1016/j.envpol.2013.10.013.

Sussarellu, R., Suquet, M., Thomas, Y., Lambert, C., Fabioux, C., Pernet, M.E.J., ... Huvet, A., 2016. Oyster reproduction is affected by exposure to polystyrene microplastics. Proc. Natl. Acad. Sci. 113 (9), 2430-2435. http://dx.doi.org/10.1073/pnas.1519019113.

Tanaka, K., Takada, H., 2016. Microplastic fragments and microbeads in digestive tracts of planktivorous fish from urban coastal waters. Sci. Rep. 6, 34,351.

http://dx.doi.org/10.1038/srep34351.

Thompson, R., Olsen, Y., Mitchell, R.P., Davis, A., Rowland, S.J., John, A.W., 2004. Lost at sea: where is all the plastic? Science 304. http://dx.doi.org/10.1126/science.1094559.

Tosetto, L., Williamson, J.E., Brown, C., 2017. Trophic transfer of microplastics does not affect fish personality. Anim. Behav. 123, 159-167. http://dx.doi.org/10.1016/j.anbehav.2016.10.035.

Van Cauwenberghe, L., Janssen, C.R., 2014. Microplastics in bivalves cultured for human consumption. Environ. Pollut. 193. http://dx.doi.org/10.1016/j.envpol.2014.06.010.

Van Cauwenberghe, L., Vanreusel, A., Mees, J., Janssen, C.R., 2013. Microplastic pollution in deep-sea sediments. Environ. Pollut. 182. http://dx.doi.org/10.1016/j.envpol.2013.08.013.

Van Cauwenberghe, L., Claessens, M., Vandegehuchte, M.B., Janssen, C.R., 2015. Microplastics are taken up by mussels (Mytilus edulis) and lugworms (Arenicola marina) living in natural habitats. Environ. Pollut. 199. http://dx.doi.org/10.1016/j.envpol.2015.01.008.

Vethaak, A.D., Leslie, H.A., 2016. Plastic debris is a human health issue. Environ. Sci. Technol. 50 (13), 6825-6826. http://dx.doi.org/10.1021/acs.est.6b02569.

Volkheimer, G., 1975. Hematogenous dissemination of ingested polyvinyl chloride particles. Ann. N. Y. Acad. Sci. 246 (1), 164-171. http://dx.doi.org/10.1111/i.17496632.1975.tb51092.x. 
von der Kammer, F., Ferguson, P.L., Holden, P.A., Masion, A., Rogers, K.R., Klaine, S.J., ... Unrine, J.M., 2012. Analysis of engineered nanomaterials in complex matrices (environment and biota): general considerations and conceptual case studies. Environ. Toxicol. Chem. 31 (1), 32-49. http://dx.doi.org/10.1002/etc.723.

Von Moos, N., Burkhardt-Holm, P., Köhler, A., 2012. Uptake and effects of microplastics on cells and tissue of the blue mussel Mytilus edulis $L$. after an experimental exposure. Environ. Sci. Technol. 46. http://dx.doi.org/10.1021/es302332w.

Vroom, R., Halsband, C., Besseling, E., Koelmans, A.A., 2016. Effects of Microplastics on Zooplankton.

Watts, A.J., Lewis, C., Goodhead, R.M., Beckett, S.J., Moger, J., Tyler, C.R., 2014. Uptake and retention of microplastics by the shore crab Carcinus maenas. Environ. Sci. Technol. 48. http://dx.doi.org/10.1021/es501090e.

Wegner, A., Besseling, E., Foekema, E.M., Kamermans, P., Koelmans, A.A., 2012. Effects of nanopolystyrene on the feeding behavior of the blue mussel (Mytilus edulis L.). Environ. Toxicol. Chem. 31 (11), 2490-2497. http://dx.doi.org/10.1002/etc.1984.

Woodall, L.C., Sanchez-Vidal, A., Canals, M., Paterson, G.L.J., Coppock, R., Sleight, V., 2014. The deep sea is a major sink for microplastic debris. R. Soc. Open Sci. 1.

http://dx.doi.org/10.1098/rsos.140317.

Wright, S.L., Kelly, F.J., 2017. Plastic and human health: a micro issue? Environ. Sci. Technol. 51 (12), 6634-6647. http://dx.doi.org/10.1021/acs.est.7b00423.

Wright, S.L., Rowe, D., Thompson, R.C., Galloway, T.S., 2013. Microplastic ingestion decreases energy reserves in marine worms. Curr. Biol. 23. http://dx.doi.org/10.1016/j.cub.2013.10.068.

Zhao, S., Zhu, L., Wang, T., Li, D., 2014. Suspended microplastics in the surface water of the Yangtze estuary system, China: first observations on occurrence, distribution. Mar. Pollut. Bull. 86. http://dx.doi.org/10.1016/j.marpolbul.2014.06.032. Ziccardi, L.M., Edgington, A., Hentz, K., Kulacki, K.J., Kane Driscoll, S., 2016.

Microplastics as vectors for bioaccumulation of hydrophobic organic chemicals in the marine environment: a state-of-the-science review. Environ. Toxicol. Chem. 35 (7), 1667-1676.

http://dx.doi.org/10.1002/etc.3461. 